\title{
Study on the Training Strategy of High Skilled Talents of Spray Coatings for Automobile in Secondary Vocational School— from the Perspective of Made in China 2025 Strategy
}

\author{
Songbo Lu* \\ Jintang Senior Vocational Middle School, Cixi, Zhejiang, 315315, China
}

ARTICLE INFO

Article history

Received: 15 May 2020

Revised: 22 May 2020

Accepted: 9 October 2020

Published Online: 16 October 2020

Keywords:

Spray Coatings for Automobile

High skilled talent

Training strategy

Made in China 2025 Strategy

\section{Introduction}

A ccording to a long-term study of the economics of agriculture form the Theodore William Schultz, the pioneer of modern human capital theory, from the beginning of the 20th century to the 1950s, the skill of workers is the key to promote the rapid growth of agricultural production and productivity in the United States, instead of the amount of land, labor, and material capital. High skilled talents are the core backbone of skilled workers, an indispensable force in promoting technological innovation and transforming scientific and technological achievements into real productive forces, an explorer, practitioner and promoter of technological

\section{ABSTRACT}

Made in China 2025 Strategy requires a large number of high skilled talents, which the high-skilled talents are the core backbone of skilled workers and a significant force to promote technological innovation and realize the transformation of scientific and technological achievements. In this study, combined with automotive spraying industry characteristics, four cultivation strategies are established by the construction of the system of high-skilled talent formation, training mode of on-campus + on-job highskilled talents, the common trail of national certification and enterprise certification and the star system spiraling excitation in order to create a new growth path for the cultivation of high-skilled talents in automobile spraying. innovation, and an important representative of advanced productivity ${ }^{[1]}$.

The research on the cultivation of high-skilled talents has always been a key research field in the process of economic transformation and upgrading and socially sustainable development of various countries. On May 8, 2015, the State Council promulgated the "Made in China 2025 Strategy" plan. After 2 years, 2017 will be the key year for China to fully implement the "Made in China 2025" strategy. Faced with the demand of "Made in China 2025 Strategy" for high skilled talents, vocational school, as a role providing front-line technical workers for enterprises, also need to carry out supply-side structural reform and ensure the supply of high skilled talents for the transfor-

*Corresponding Author:

Songbo Lu,

Address: No.139 Jintang Village, Guanhaiwei Town, Cixi City, Zhejiang Province, Jintang Senior Vocational Middle School, Cixi city, Zhejiang Province, China;

E-mail:LSBLL2002@163.COM. 
mation and upgrading of enterprises and realization of the intelligent manufacturing.

Through the more than 100 years' development, the automobile industry has become one of the largest and most important industries in the world. Recently, there is a steady growth trend for global automobile production and sales volume basically. In 2016, the global automobile production and sales reached a new high, with a yield of 94.98 million and a sales volume of 93.86 million. The annual compound growth rate of global automobile sales in 2009-2016 is 3.26\%. In China, automobile production and sales volume grew steadily, with the production and sales volume of passenger vehicles of 21.08 million sets and 21.15 million sets, respectively in 2015 , and with the year-on-year growth of $5.78 \%$ and $7.30 \%$. In 2016 , the production and sales of automobiles were 28.1188 million and 28.0282 million, with a year-on-year growth of $14.46 \%$ and $13.65 \%$, including 24.4207 million and 24.3769 million passenger cars, with a year-on-year growth of $15.50 \%$ and $14.93 \%$. Verband der Automobilindustrie VDA predicted that global automobile sales volume would be expected to 85.7 million units with a growth of $1 \%$ in 2018 . China will remain the world's largest market in 2018, rising $2 \%$ to around 25 million units.

The automotive aftermarket develops rapidly with the development of spray coatings for the automobile industry, and in the field of spray coatings for automobile advantages are an increasingly prominent phenomenon. The total annual output value of spray coatings for the automobile industry is nearly 10 billion yuan, and the total demand for automobile repair paint is nearly 2 billion yuan. Recently, in China, the general development trend of spray coatings for the automobile shows the trend of intelligent and individuation ${ }^{[2]}$. In the field of spray coatings for automobiles, the rapid development and the development trend of gradual intelligence and individuation are badly in need of a large number of high-skilled talents in this industry.

\section{Current Situation of Skilled Talents in Spray Coatings for the Automobile Industry}

\subsection{Insufficient Number of Skilled Talents in Spray Coatings for the Automobile Industry}

By the end of 2017, the incomplete statistics showed that there were about 850,000 spray coatings for automobile technicians in China. Every year, 5800 students graduate from secondary vocational and higher vocational colleges majoring in spray coating for automobiles. Recently, the average year of establishment of spray coating for automobiles in all secondary vocational and higher vocational colleges is 8 years, and about 46,000 spray coating for automobile technicians includes that finish the education of the vocational colleges and signs up by themselves to participate in the vocational skills training and appraisal in various provinces and cities, with the huge gap of 600,000 technicians.

In the better automobile maintenance enterprise, sheet-metal spray paint maintenance reaches $400-500$ unit-time every month, and each spray paint technician can create a man-hour benefit of 80,000-100,000 yuan monthly. In China, the continuous development of the automobile market will make more excellent automobile after-sales maintenance enterprises and make the demand for excellent skilled talents grow.

\subsection{The Low Quality of Skilled Talents in Spray Coating for Automobile Industry}

The corporate research of nearly 100 automobile maintenance enterprises in Zhejiang Province showed that 24.4\% of the staff did not obtain the professional qualification certificate of spray coating for automobiles, and $43.6 \%$ of the staff only qualified the junior high school education, as shown in Table 1. In the spray coatings for the automobile industry, the skilled talents are low quantity and large employee turnover.

Table 1. proportion list professional qualification level, education background and working years of technicians in spray coating for the automobile industry

\begin{tabular}{|c|c|c|c|c|c|}
\hline $\begin{array}{c}\text { Occupational } \\
\text { qualifications } \\
\text { grade }\end{array}$ & Proportion & $\begin{array}{c}\text { Education } \\
\text { level }\end{array}$ & Proportion & $\begin{array}{c}\text { Working } \\
\text { years }\end{array}$ & Proportion \\
\hline $\begin{array}{l}\text { Primary } \\
\text { worker }\end{array}$ & $20.3 \%$ & $\begin{array}{c}\text { Below junior } \\
\text { high school } \\
\text { degree }\end{array}$ & $43.6 \%$ & $\begin{array}{l}\text { Less } \\
\text { than } 1 \\
\text { year }\end{array}$ & $14.5 \%$ \\
\hline $\begin{array}{c}\text { Intermediate } \\
\text { worker }\end{array}$ & $32.7 \%$ & $\begin{array}{c}\text { Junior high } \\
\text { school degree }\end{array}$ & $21.8 \%$ & $1-3$ years & $24.5 \%$ \\
\hline Senior worker & $15.3 \%$ & $\begin{array}{c}\text { High school } \\
\text { degree }\end{array}$ & $32.7 \%$ & $3-5$ years & $32.7 \%$ \\
\hline Technician & $5.5 \%$ & $\begin{array}{c}\text { Junior college } \\
\text { degree }\end{array}$ & $1.8 \%$ & $\begin{array}{l}\text { More } \\
\text { than } 5 \\
\text { years }\end{array}$ & $27.3 \%$ \\
\hline $\begin{array}{c}\text { Senior } \\
\text { technician }\end{array}$ & $1.8 \%$ & $\begin{array}{l}\text { Undergraduate } \\
\text { college degree }\end{array}$ & $0 \%$ & & \\
\hline $\begin{array}{c}\text { No } \\
\text { occupational } \\
\text { qualification } \\
\text { certificate }\end{array}$ & $24.4 \%$ & & & & \\
\hline
\end{tabular}


2.3 Unreasonable Structure of Skilled Talents in Spray Coatings for the Automobile Industry

According to the investigation of 15 automobile maintenance enterprises of different scales in Jiashan District, Zhejiang Province, the proportion of talent type structure of spray coating for automobiles is shown in Table 2, with freshman (apprentice) of $25 \%$, skilled worker of $18 \%$, intermediate worker of $40 \%$, senior worker of $17 \%$ and technician and senior technician of $0 \%$, which high skilled talent is scarce with the extremely unreasonable structure of skilled talents.

Table 2. Talent type structure of spray coating for automobiles in Jiashan District of Zhejiang Province

\begin{tabular}{|c|c|c|c|c|c|c|c|}
\hline Talent type & Proportion & Talent type & Proportion & Talent type & Proportion & Talent type & Proportion \\
\hline Freshman & $25 \%$ & Skilled worker & $18 \%$ & Intermediate worker & $40 \%$ & Senior worker & $17 \%$ \\
\hline
\end{tabular}

\section{Problems in the Training of High-Skilled Talents}

"The Medium and Long Term Plan for the Construction of High Skilled Talents (2010-2020)" clearly defines "high skilled talents": it refers that the people with superb skill and exquisite technical ability, has the ability to perform creative work and contribute to the society, which these mainly include the people obtaining the occupational qualifications of senior technicians and senior technicians among the skilled workers, and this personnel are the personnel of the Grade 3, Grade 2 and Grade1 in these occupational qualification grades. Recently, the process of training highly skilled talents mainly exist the following problems:

\subsection{Lack of Skills Formation Path for Sustainable Improvement}

The formation of skills needs to constantly accumulate, especially the formation of high-skilled. The high-skilled can only be accumulated by continuous training and proficiency. Skills accumulation needs a platform, and the establishment of the platform is key to a sound high skill formation of curriculum system besides the policy guarantee, the school-enterprise cooperation incentive mechanism, and other factors. Recently, the national vocational qualification certification exists the problem that certification contents update slowly, training appraisal is uneven, the industry dynamic is short of the sustainable development concept and the training of high-skilled talents is lack of the path of sustainable development.

\subsection{Few Ways of Certification of High-Skilled Talents}

At present, in China, the high-skilled talents are identified by obtaining national vocational qualification certificates for the senior worker, technician, and senior technician. As the object of the certification of high-skilled talents, few paths are in the process of the identification of highskilled talents, and there is a lack of identification methods and measures for other types of high-skilled talents.

\subsection{Lack of Corresponding Evaluation and Incentive Mechanism}

High-skilled talents are cultivated by a process of continuous improvement and dynamic development. The cultivation of a high-skilled talent needs to take as little as a few years or more than a decade. The formation of highskilled talents requires not only their own needs and motivations but also corresponding incentive policies. Currently, the certification standard of high-skilled talents is identified by the only national vocational qualification, but meanwhile, we lack innovation and continuous promotion of high - skilled talents evaluation incentive mechanism.

\section{The Requirements of Made in China 2025 Strategy on Spray Coatings for Automobile Skilled Talents}

Made in China 2025 strategy proposes 9 tasks and 9 tasks can extract 6 keywords. The 6 words combine the connotation of Made in China 2025 Strategy, namely "innovation + integration + brand + Green + service + internationalization". ${ }^{[3]}$ The new connotation of Made in China 2025 Strategy proposes the new requirements for the skilled talents of spray costing for automobiles.

\subsection{Grasp the Development of the Industry and Have a Unique Sense of Innovation}

Innovation is the fundamental driving force for economic growth and the endogenous force for the development of China's manufacturing industry. The "Widespread Entrepreneurship and Innovation" advocated by the government will create a good ecological environment for the innovation and development of the manufacturing industry. According to the new connotation of Made in China 2025 
Strategy, spray coatings for automobile skilled talents must constantly grasp the development trend of the auto paint industry, update concepts and innovating, in order to reach to the new requirements of made in China 2025 strategy for skilled talents.

\subsection{Follow the Internet +, Cross-Border Industry Integration}

The "China "intelligent manufacturing" is the key to realize the Made in China 2025 Strategy, while "intelligent manufacturing" depends on Internet + . The spray coatings for automobile skilled talents need to integrate the Internet with the automotive paint industry, promote intelligent spraying, and achieve the integration of the Internet industry and the automotive paint industry.

\subsection{Strengthen Skill Improvement and Focus on Brand Awareness}

A brand represents the comprehensive quality of goods and is an important way to enhance the added value of products. According to the new connotation of Made in China 2025 Strategy, the made in China need to be guaranteed by continuously strengthening the skill improvement and focusing on the brand construction of the industry.

\subsection{Advocate Green Manufacturing and Realize Sustainable Development}

Green manufacturing is an inevitable course to make in China. Only environmentally friendly production modes can become the mainstream direction of China's manufacturing industry. The development of spray coatings for the automobile industry only adheres to the principle of green manufacturing and green production to achieve sustainable development of the industry. Green is the main theme and the lifeline of development to train high-skilled talents for spray coatings for automobiles.

\subsection{Focus on Service Consciousness and Expand the International View}

In global economic integration times, people from all walks of life are expected to an international view and the ability that participate in the international division of labor and international competition to obtain profit maximization. The spray coating for the automobile industry, although only a small branch industry, is a permanent event in the world skills competition, which in this industry if high-skilled talents hope to contribute to the Made in China 2025 Strategy in an International environment, they must focus on service awareness and constantly expand their international view.

\section{Training Strategies for Spray Coatings for Automobile High Skilled Talents}

\subsection{Establish a Skill Formation System for Spray Coatings for Automobile High Skilled Talents}

High skilled talents are in the high-end of skilled talents, so they are also called high-end skilled talents ${ }^{[4]}$. This group is gradually grown up to truly become high skilled talents and be used by enterprises ${ }^{[5]}$. The spray coatings for the automobile industry is in urgent need of a large number of highly skilled talents. Only build a set of spray coating for automobile high skilled talents skills formation system, and comply with the principle of step-by-step, can train a batch of high-skilled talents in the spray coating for the automobile industry.

According to the industry characteristics and skill formation rules of spray coating for the automobile industry, 145 skill formation system of spray coating for automobiles is set through research. 1 is a passing skill, i.e. shield skill; 4 is four basic skills, i.e. grinding, spraying (include two directions of primer and finishing coat), polishing and color matching. They are shown in Figure 1.

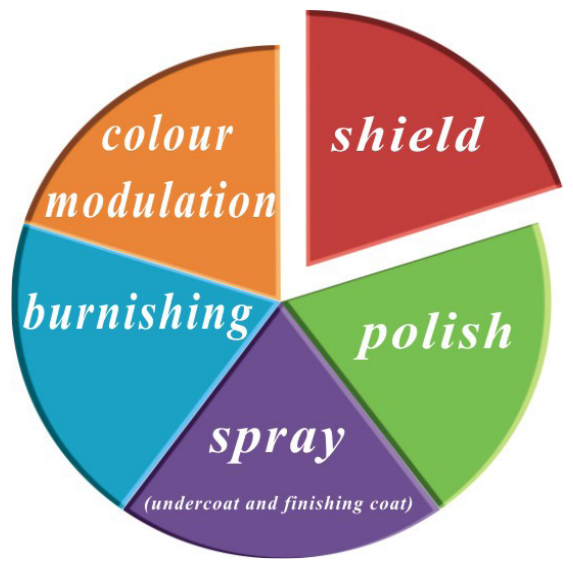

Figure 1. The composition of pass skills and basic skills

5 is 5 skill promotion levels (i.e. star level) among the basic skills. According to the principle of progressive skill formation, 5 skill promotion levels are set up respectively, which provide a rating system for the subsequent star-level system of assessment, promotion and incentive, as shown in figure 2-6.

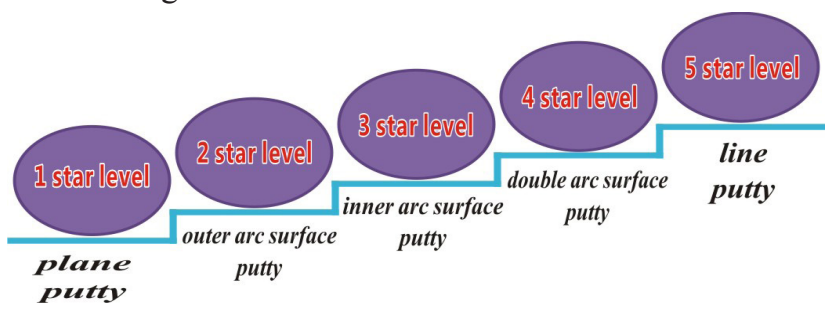


Figure 2. Star level improvement figure of basic skills for grinding

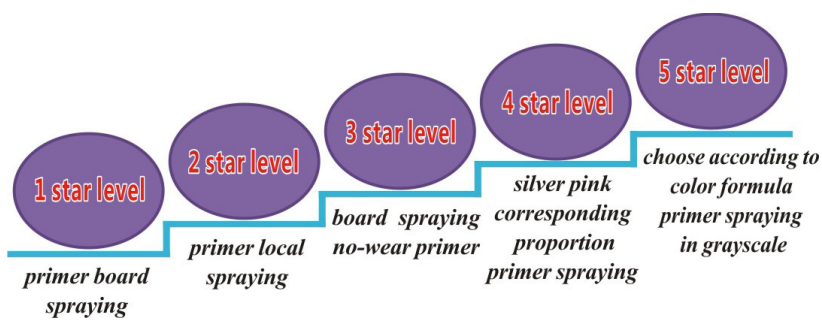

Figure 3. Improvement figure of basic spraying (primer) skills star level

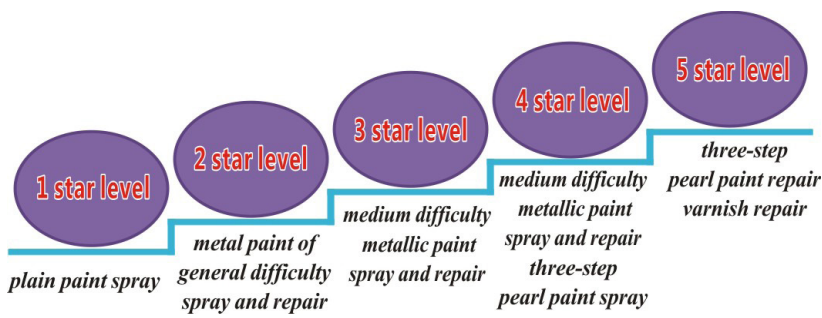

Figure 4. Improvement figure of basic skills of painting finish star level

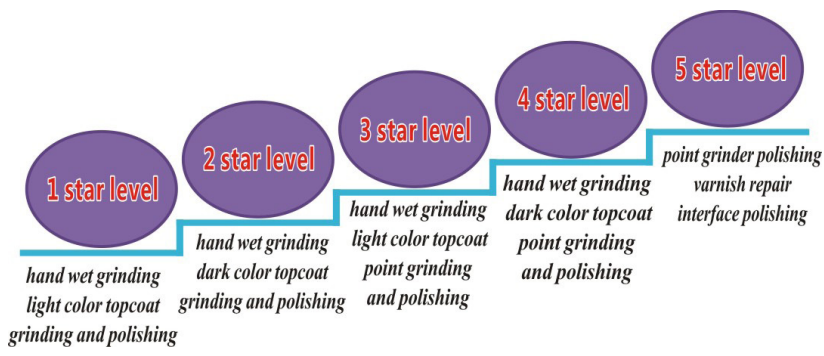

Figure 5. Improvement figure for polishing basic skills star level

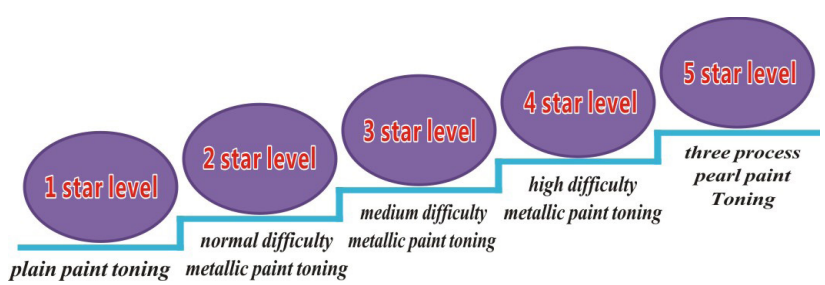

Figure 6. Improvement figure of basic skills of color matching star level

The 145 system constructs a complete formation system formed of spray coatings for automobile high-skilled talents, covers all aspects of the skills, highlights the progressive rule of the formation of skills, and builds a learning path for the sustainable development of high-skilled talents.

\subsection{Build a System of Spray Coatings for Automobile High Skilled Talents on School + On Job Skill Training}

For the lifelong education system, modern high skilled talents can grow in many paths, of which the two models are representative: (1) the post intensifies the exercise pattern under the academic education and this is a growth model of learning - practice - learning - practice; (2) the school intensifies the training mode after the post-selection and training, and this is a growth mode of practice-learning-practice-learning ${ }^{[6]}$. Under the background of academic education, the post strengthening exercise mode and the school strengthening training mode after the post-selection and training are both single. In this study, according to the trinity training path of secondary vocational, higher vocational, and on - job, the school, and on-the-job training are combined organically to make the training of high-skilled talents connect the school with the enterprise, and form the mixed path of high skilled talents training. According to direct employment after vocational education and reemployment after higher vocational, the school + on-the-job training is divided into two modes, one is the vocational school + senior vocational + employment mode, that is, $3+3+6$ mode; The other is secondary vocational + employment mode, that is, $3+9$ mode. The mixed training mode of "in school + on job" is shown in Figure 7.

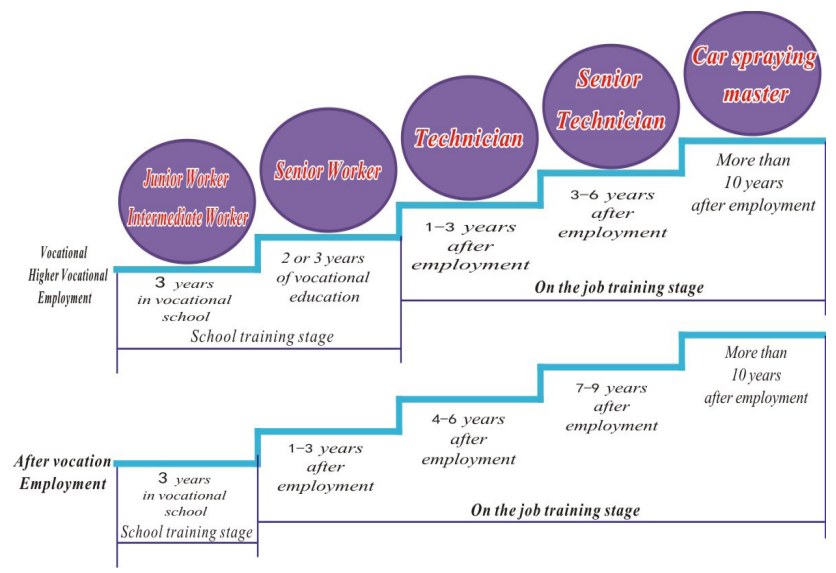

Figure 7. Mixed training mode figure of school + on job

\subsection{Build a Common System of National Certification and Enterprise Certification for High Skilled Talents in Spray Companies for Automobile}

The construction of the common track system of national research and enterprise certification organically integrates the national certification path of high skilled talents with 
the enterprise's demand path for high skilled talents, which both avoids the phenomenon that some appraisal agencies have poor quality control, and high-skilled talents are shown that high certification and low technical, and dynamically optimize the actual needs of enterprises, and the training of high-skilled talents is solid step by step and keeps rising steadily through the star-level method.
The dynamic optimization of star assessment content benefits to the rapid permeability of new technology and new process, makes the green manufacturing and international vision permeate and expends and form a common track training and certification system for high skilled talents of spray coating for automobile, as shown in Figure 8.

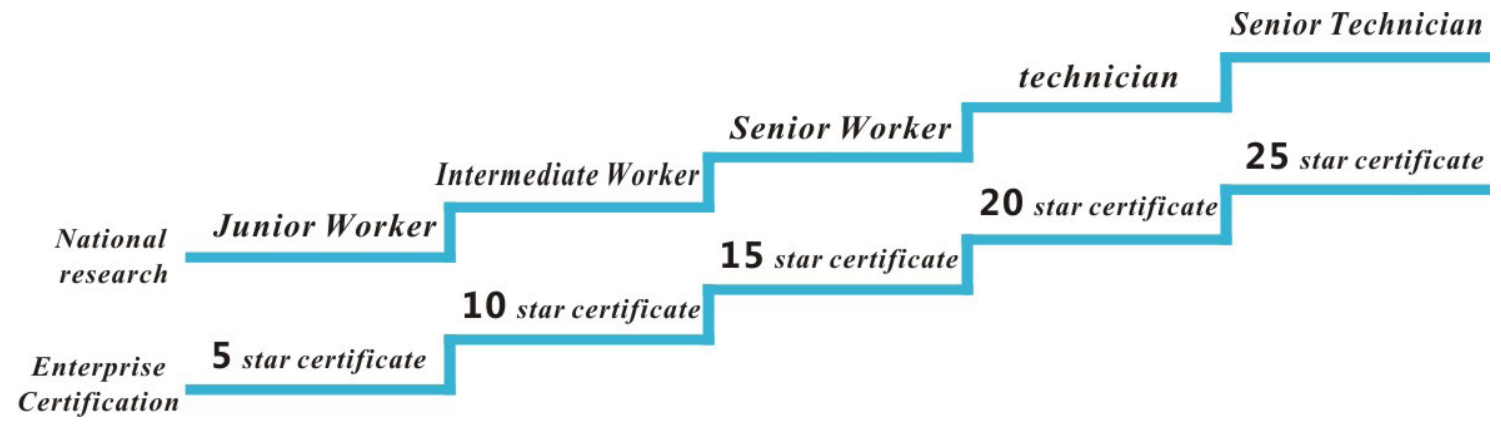

Figure 8. Common track figure of national certification and enterprise certification system

\subsection{Build a Spiral Incentive System of the Star System for High Skilled Talents in Spray Coatings for Automobile}

In psychology, expectation theory points out that the degree to which a person's motivation is activated depends on the product of the expected value and the valence. That is to say, the greater grasp of the objective is, the higher the estimated probability of reaching the goal is, the stronger the motivation aroused, and the greater the enthusiasm is. In spray coatings for automobile high-skilled talents cultivation system, according to the theory of psycholog- ical expectation, the formulated star-level spiral-rising incentive system is spiraled as the stage and gradient, and from the point to the surface, and from the low star level to the higher ones, the high-skilled talents gradually complete the training. Meanwhile, each star corresponds to the salary. The rise of star level both represents the rise of salary, and represents the rise of skill level. From junior workers to senior technicians, they finally become masters of spray coating for automobiles. Figure 9 shows the correspondence between enterprise certification star level and national occupation grade.

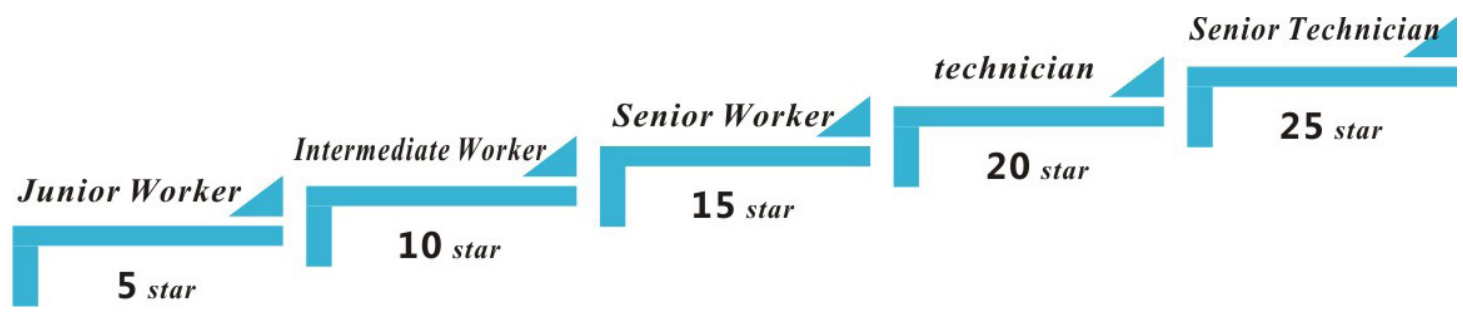

Figure 9. Correspondence diagram between enterprise certification star level and national occupation level

\section{Conclusion}

High-skilled talents are the key factor to transform science and technology into practical productive force, one of the representatives of high quality and high efficiency, and the carrier of core competitiveness and advanced productivity. If the high-skilled talents, and high-quality and low-cost products and services are owned, it will obtain the core competitiveness and the initiative to win the market competition $^{[7]}$. Through the construction of the skills formation system of high skilled talents, the training mode system of "in school + on job" high skilled talents, the common track system of national certification and enterprise certification, and the star system spiral incentive system, a new 
growth path has been created for the cultivation of high skilled talents in spray coating for automobiles ${ }^{[8]}$. But the training of high-skilled talents is a dynamic development process. With the development of society and industry, there will be more innovative and effective training strategies in the future.

\section{References}

[1] Ma Qing, Zhang Zilin. Research on the Training strategy of High-skilled Talents in Jilin Province [J]. Journal of Beihua University, 2006.

[2] Zhu Ke. Discussion on the Advantages, Current Situation and Development Trend of Spray Coatings for Automobile Industry [J]. China Science and Technology, 2017 (01): 239-242.

[3] Zhang Li. Interpretation of Made in China 2025 Strategy [J]. China Today, July 15, 2015.

[4] Shanghai Academy of Educational Sciences, Mycos
Research Institute. 2012 China Higher Vocational Education Talent Training Quality Annual Report [R]. Beijing: Foreign Language Teaching and Research Press, 2012 (06): 2-3.

[5] Lu Zhimi. The Practical Path of High-skilled Talents Training in the Open Economic Pattern [J]. Vocational Education Forum, 2013 (08): 61.

[6] Zhang Yue. Study on the Training Mode of Highskilled Talents in China -- Taking LB College as an Example [D]. Shanghai: East China Normal University, 2014.

[7] Liu Qingtang. My Opinion on Training High-skilled Talents [J]. Journal of Beijing Institute of Planned Labor Management, 2005 (03): 25.

[8] Yin Weimin, Speech by Minister Yin Weimin at the 12th High-skilled Talents Commendation Conference[J]. China Training. 2015 (02):15. 